\title{
Morphopedology of the Saharan Soils The Valley of Oued Righ. Algeria
}

\author{
Boumaraf Belkacem ${ }^{1}$,Saadi Inesse ${ }^{2}$, Alain Marre ${ }^{3}$. Rabah Bensaid ${ }^{4}$
}

\begin{abstract}
Algeria is the first country in Africa by its surface area $(2,381,741 \mathrm{Km} 2)$, of which four-fifths are occupied by the Sahara. The Saharan regions are a source of natural diversity, economic wealth and social exchanges, After a phase of stagnation or decline, it has evolved from the structural point of view during the last two decades. Then we see a revival that is expressed not only through the extension of the palme grove zones, but also by the introduction of new production systems Modern soil characterization stems primarily from the nature of pedogenesis that spawned them and pedo-climatic conditions that president for their operation in the arid regions implementing culture of these spaces shall not be subject to benchmarks analog assessment based only on a soil characterization based on physico-chemical that however certain analytical procedures are deficient for soil accumulations salines and especially soil gypseous but a complete study (mineral and microscopic) analysis associated with a precise knowledge of the landscape as the evolutionary aspect of these soils and the results between pedogenesis processes and Morphogenesis it becomes imperative to link former and current environment thanks to the geomorphological surveys, microscopic and diffractometric
\end{abstract}

Key words: Sahara, Algeria, geomorphology, pedology, Chott, glacis, mineralogy, salinity, gypsum

\section{INTRODUCTION}

The oasis of the Valley of Oued Righ extend on almost 150 $\mathrm{Km}$ of Oum Thiour northward to El Goug to the South. They are considered as the main agriculture of the North Eastern Sahara area. Despite being under the influence of a dry and arid climate. These oases consist of small properties that seldom reach a hectare, the product of small surfaces, can be sufficient if the operation is highly intensive. Unfortunately and contrary to appearances, the Saharan farm is by tradition of extensive type.

All these Palm trees even though, they are different by their importance and their vocation, are cratered by the fragility of their ecosystem threatened to rupture due to numerous factors: the aging of palm groves, the non observance of the planting density, abusive exploitation without significant restitution or crop rotation... at the same time the contrast is more accentuated by the appearance of uncultivated soils surrounding acreage.

1: Doctor University Of Biskra.(Algéria).2: Master Wizard University Of Biskra (Algéria).. .3: Professor University Of Reims (France).4 : University Of Skikda (Algéria).
The incessant need of a population by rapid population growth, the introduction of new irrigated areas becomes imperative to maintain the socio-economic balance in this region.

It is essential to recall that genetic characterization of soils in a Saharan context leads, the soil scientist to a knowledge of the geomorphologic framework in which these soils, it is also established now that cannot be explained, in function only vertical material migration, their interdependence with those who surround them especially that however the notion of topo-sequence results from this consideration based on single topographic differentiation and remains insufficient because it risk of lead has a confrontation of soils of different age.

Thus, the solution to most problems requires a comprehensive analysis field. 1 'study of recent formations is in this vital respect and it must be carried out both in the direction of morpho-pedology, geomorphological analysis of the Sahara should be systematically undertaken because it is intimately linked to hydrogeology and pedology it appears in fact indispensable to any test development of Sahara [1]

\section{MATERIAL AND METHODS}

2.1 geographical situation

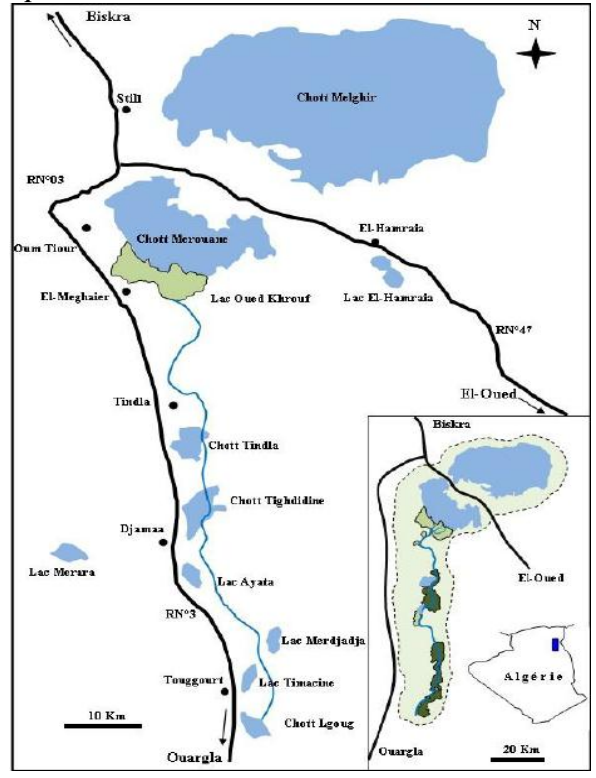

Figure: 1 - the geographic location of the Valley of the OUED RIGH [2] 
The Valley of OUED RIGH is situated in the North - East Saharan Algeria, along the great Eastern Erg and the South of the massif of the Aurès (fig.1). It presents itself as a kind of very flattened gutter 15 to $30 \mathrm{Km}$ wide and extends over 150 $\mathrm{Km}$, on a North-South axis between latitude $32^{\circ} 45^{\prime}-34^{\circ} 30^{\prime}$ and longitude $5^{\circ} 45$ and $6^{\circ} 15$

\subsection{The Geomorphological Mapping}

The geomorphological study is based on a systematic mapping [3] [4]. It helped to show the existence of five geomorphological levels stacked with the background of the Chott Mason and four glaze (Fig. 2)

\subsubsection{The bottom of the Merouane Chott, the lower level 0}

This level corresponds to the current bowl of settling with soils pseudogley. Covered white Salant characteristic, (the great chott) with a absolute absence vegetation it offers a remarkably flat topography. (elevation10 a-35 m) Characterized by a carpet of salt crystals white, of different types, (sulphate and chloride). In some areas, surface, becomes by its consistency a viscous crust and crunchy.

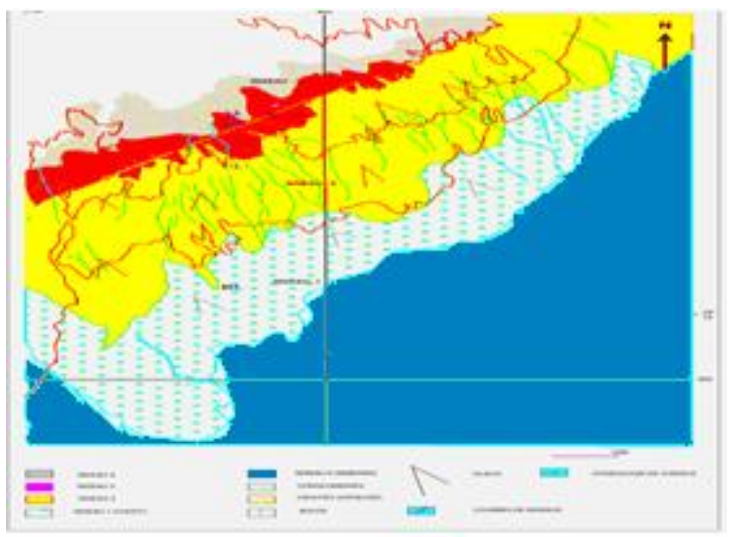

Figure: 2 - geomorphological map of the area showing the location of the profiles

\subsubsection{The lower glaze of level 1}

Noticeable by a passage to a higher threshold, with a transition sometimes inconspicuous, an extremely short concavity, and or the density of halophytic plants become more numerous. Located in silt saturated with salts and which marks the passage to the Chott. He characterized by clayey silty-sandy soils. It is a fringe of large Chott.

\subsubsection{The average glaze of level 2}

This level appears a few meters fitted with the previous. It presents itself as a great glaze, very low slope. It is characterized by soils to gypsums accumulation, distinguished by gypsums scabbing and crusting at varying depths. Invaded by the nebkas that there are favorable conditions for their formation, (the proximity of groundwater) and gives the overall landscape a bumpy appearance. The surface of this level to an area greater than that of neighboring levels

\section{2.4 The high glaze of level 3}

These is a erosion glaze defined by some inclined surfaces. A variable slope of $5 \%$ to $15 \%$ to swallows it with a reduced spatial extension, very variable compared to the preceding level. Piedmont becomes slightly concave offering the training aspect perched. Hydrographic and more pronounced network upstream by the deep ravine of 20 to $40 \mathrm{~cm}$, and to swallows it rare flutes. On the surface, there are very regular basis, thick gypsums crust, presumably period pen planation developed on miopliocene materials [2]

\subsubsection{The very high glaze level 4}

This level is represented by a huge glaze, dominating the northern part of the Valley by a steep of several tens of meters. These formations are top crusts (figure 3) consist of crumbly clumps and glued nodules layer harder gypsolimestone. At its base, a consolidated marl substrate. The scabbing and crusting, glassy structure marry topography. Observed on the surface of the debris in holes of varying sizes. Covered by a veil of sandy and loose cover composed of xerophytes reaching rarely $50 \mathrm{~cm}$. . This level bears some traces of flow reduced to a few tens of centimetres hack

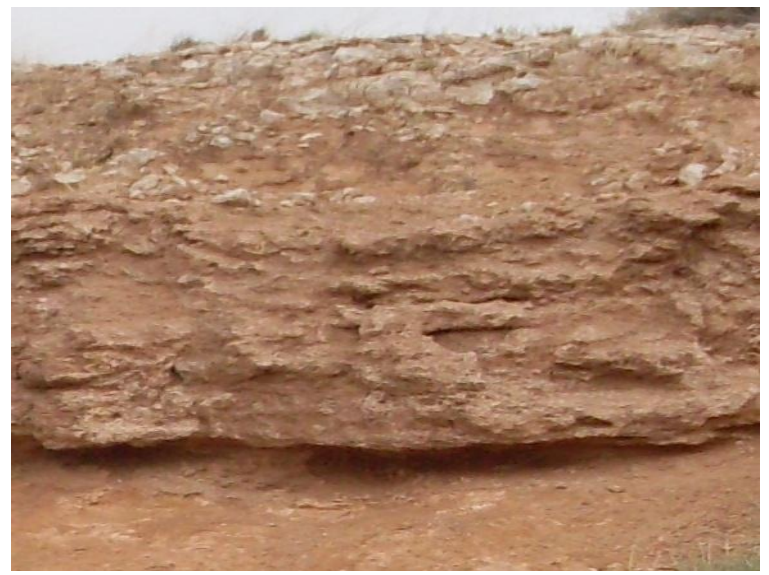

Fig 3 ; Morphology laminated crusts and cobalt in-level 4 [5]

Covered with a veil of Eolian sand, the General texture of the studied soil is almost uniform surface (except for the fringe of the chott covered by a dense halophyte vegetation). By cons for the subsurface horizons, the texture becomes more fine to swallows it (level 1 and 2). The transition between the sharper horizons. The solution of the soil and virtually dominated by the sodium, and offer a slightly alkaline to alkaline $\mathrm{pH}$, due to proximity to groundwater very loaded in salts (table 1)〉

TABLE 1: ANALYTIC RESULTS OF GROUNDWATER

\begin{tabular}{|c|c|c|c|c|}
\hline \multirow{9}{*}{$\begin{array}{l}\text { Depth } \\
>65 \\
(\mathrm{~cm})\end{array}$} & PH & 8.1 & ES (g/l) & 38.22 \\
\hline & $\mathrm{Cl}^{-}$ & 616.2 & $\Sigma^{-}$ & 759.4 \\
\hline & $\mathrm{So}_{4--}$ & 136.4 & $\Sigma^{+}$ & 788.79 \\
\hline & $\mathrm{HCo}_{3}$ & 6.8 & $\Sigma$ & \\
\hline & $\mathrm{Na}^{+}$ & 456.43 & I & 1.03 \\
\hline & & & $\Sigma+$ & \\
\hline & $\mathbf{K}^{+}$ & 31.2 & SAR & 37.2 \\
\hline & $\mathbf{M g}^{++}$ & 108.56 & $\mathrm{Cl}^{*}$ & \\
\hline & $\mathrm{Ca}^{++}$ & 192.6 & $\begin{array}{c}/ \\
\text { So4- }\end{array}$ & 4.51 \\
\hline
\end{tabular}




\section{Analysis of physicochemical and mineralogical results}

The salt profiles vary from one level to another and sometimes in the same level (case of level 2), it is oriented with a maximum of salinity towards the top of the profile (hyper-epipedonique) as is the case of the profile D2 in level 1 and profile A3 in the level 4, and for level 3 . The electrical conductivity is more important than the underground horizons. This variation indicates to us that the salinity is rising under the effect of climate aspiration from groundwater or due to an accumulation on the surface of grains of salt transposed by the wind from the great chotts

The effect of groundwater in salts is especially expressed in levels 1 and 2 by various forms of gypsums accumulations, however for levels 3 and 4 are exclusively of wind origin. In level 2, the salt profile offers variations observed in the surveys and profiles (high and low value checked in epipedon. Despite the proximity to the water, this variation is due to the presence of a gypsum crust that hinders the reassembled salts to the surface .

3 and 4 glaze soils are shallow with rough conglomeratic blankets. They have annoying edaphic constraints for development, due to the presence of almost continuous gypsum crust on the surface, or in depth. For levels 2 and 1 textural composition is sandy-gypsums initially, (level 2) and which becomes finer downstream. Level 2 occupies a larger area. There are more traces of gullies upstream level 2, with a background filled with coarse sand with a high proportion of gravel.

Forms of gypsums accumulations are distinguished in the levels 2 micro and macroscopic (powdery, lenticular, acicular, pink sands.) . Total limestone remains significantly low on almost all levels (except the level 4), as well as the capacity of cationic Exchange.

In mineralogical terms gypsum and quartz it remain the most minerals in mineralogical processions on all glazes. However, we find in level 1 that gypsum is more present in deep horizons than those of surface. This is due to the high ion concentration, which promotes its solubilization. Secondary minerals (kaolinite and illite, smectite, attapulgite have some variances distribution vertical and lateral in levels 1 and 2. Thus attapulgite, absent in the horizon of surface of level 1 and level 2 petrogypsic horizon. The near-absence of smectite in the niveau.1. Chlorite in level 2 shows more intense peaks because of the ion concentration in the soil. Finally, the illite are present on all diffract grams of these levels.

For levels 3 and 4, we detect the presence of secondary minerals on the two glazes, with the presence of attapulgite only in profiles located at the borders of the two levels. This correspondence between the processions of both supported the idea of the detrital clay minerals of level 3 .

The results of mineralogical analyses show that the identified minerals are derived from an inheritance. However one must make a distinction between the upstream and downstream of the Valley of the Oued Righ. Swallow, the Saharan climate current accuses a rainfall deficit, and does not offer conditions for the eventual reorganization of the silicate minerals originally degraded upstream. Only the wind is the agent of mobilization of particles capable of creating a spatial distribution of secondary minerals beyond the limits of the Sahara down.

Downstream, seasonal fluctuations in the groundwater level allow the silicate minerals to find environments rich in basic ions that provide storage conditions or even transformation by aggradation of their crystalline networks (case of the illite and chlorite). Rest however, gypsum identified on all levels destroyed during its precipitation some minerals by the force of pressure it exerts. [6] showed that gypsum invaded, destroyed and blocks the evolution of calcareous accumulations as crystallization of gypsum (1100 $\mathrm{km} / \mathrm{cm}^{2}$ ) pressure destroyed the carbonate aggregates. Robert et al. 1987, make the same determination for quartz and other secondary minerals. (figure 4)

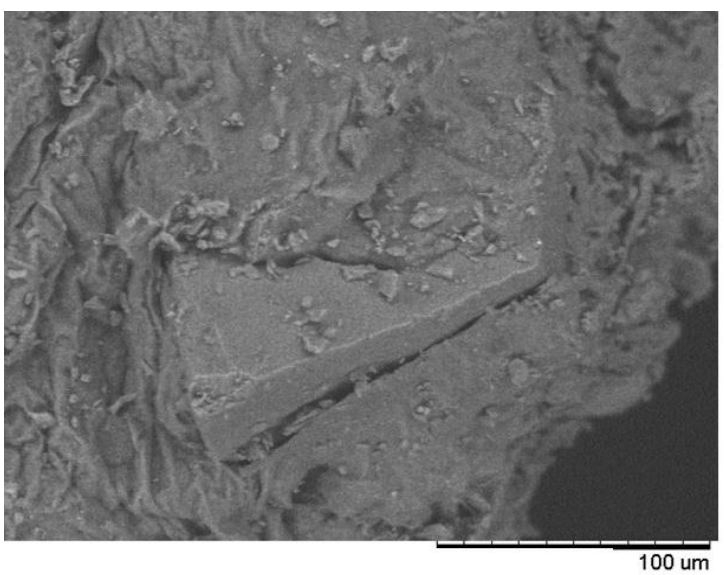

Fig 4: Crystals of calcite agglutinated by gypsum [5]

We note also the Mineralogical procession of the crust and cobalt in levels 1 and 2 (except attapulgite) are relatively the same for underneath horizons. That explains that this consolidation is posterior to the formation of these glazes.

\section{CONCLUSION}

From the elements collected through geomorphological and pedological studies, genetic characteristics of soils in our study area are divided into two separate territories. The first is not subject to the current influence of the groundwater. The second, located at the foot of the first towards the sebkha is or on the contrary, under the continual influence of this slick and these salt accumulations that it generates this layer

Its effects are accentuated by the lack of a vegetation cover in particular at the level of the sebkhas where training of saline particles transposed by the wind causes a secondary salinization on the surfaces studied and even to the beyond. Thus explained the presence of gypsums crust on superieurs.la levels or the current effect of groundwater is non-existent. With regard to the Mineralogical results on samples of the different geomorphological levels, the distribution of clay minerals in our landscape especially obeys a distribution format managed by the wind to the upper levels ( 3 and 4). The part of the inheritance of phyllitic minerals and almost exclusive with the exception of attapulgite, mineral fibrous detected in profile $\mathrm{A} 3$, could be following a neoformation [7]. However, in all levels, side intake of sulphate from closed depression contributed to the 
neoformation of gypsum, its petrification and his thickening (especially in levels 3 and 4). In case, for the level 1 and 2, under the influence of groundwater, and where the Ionic richness of the soil solution helps the transformation by aggradation of some silicate minerals. This process is unprecedented in these Saharan regions (the case of chlorite which the peak amplitudes are important values in level 2 compared to those in levels 3 and 4), or even to their eventual neoformation,. For newly gypsum remains the most distinguished in the procession, it grows at the expense of other secondary minerals. However the diffractometric results reveal that the consolidation of the scabs and crusts in the level 2 is posterior to the formation of this glaciated

In this work, we found the inexistence of such approaches for these regions and failures arising therefrom. Soil studies conducted previously in the Saharan regions [8] [9] [10] are still limited in space to interpret the pedogenic processes in a spatial and temporal framework as is the case types of floors such as paleosols. We currently have in this region can geomorphological sketches that offers passable data. These studies would move from the simple soil soil to a more detailed morphopedologique map and exploitable by any other discipline, because have may engraft on cartographic studies of various nature (map of cultural aptitude, risk map.)

\section{BIBLIOGRAPHIE}

[1] Boumaraf B, BENSAID R, MARre A,2014 : The spatial apportionment pedogenetiques soils processes in wadi righ (north eastern sahara) vallee a mineralogique approach. Annals of the University of Oradea, Geography Series /ed nalele Universitatii din Oradea, Seria Geografie . Jun2014, Vol. 24 Issue 1, p55-58. 4p

[2] BaLlaIS J.L (2010) : Des oueds mythiques aux rivières artificielles : l'hydrographie du Bas-Sahara Algérien. Physio-géo .vol 4 .2010.p107-127

[3] Gueremy P. ET MarRe A. (1996) - Une nouvelle méthode de cartographie géomorphologique applicable aux aléas naturels. Travaux de l'Institut de Géographie de Reims, nº 93-94, Reims, p. 540

[4] MARRE.A., (2007): Cartographie géomorphologique et cartographie des risques. Bulletin de l'Association des Géographes Français, $\mathrm{n}^{\circ} 1$ ("Géographies"), p. 3-21.

[5] Boumaeaf B 2014: Paysages et sols dans le Sahara.La morphopédogénèse de la vallée d'Oued Righ Sahara Nord Oriental. edition presse académique frncophone $.120 \mathrm{p}$

[6] Halitim.A, (1998): La croute de surface des sols en zone aride d'Algérie : Caractéristiques, mécanismes de formation et conséquence sur la désertification. $16^{\text {em }}$ congré mondial sur l'étude des sols, Symposium $\mathrm{N}^{\circ} 31, \mathrm{n}^{\circ}$ d'enregistrement : $1499,4 \mathrm{p}$

[7] PAQUeT .H. (1969): Evolution géochimique des minéraux argileux dans les altérations et les sols des climats méditerranéens et tropicaux à saisons contrastées. Thèse Sci. Strasbourg et Mém. Ser. Carte géol. Als. Lorr., 30, (1970), 212 p.

[8] DuRAND.J, (1958): Les sols irrigables (Etude Pédologique) Dir. Hyd. et Eco Agr Alger, 190p.

[9] Fournet.A,(1969) Etude pédologique de la dorsale tunisienne. Thèse doctorat université de Paris $175 \mathrm{p}$

[10] DuTIL.P, (1971) : Contribution à l'étude des sols et des paléosols de Sahara. Thèse doc. D'état, Faculté des sciences de l'université de Strasbourg. 346p 